\title{
Research on Ideological and Political Education of Southwest Petroleum University Students in Micro Blog Era
}

\author{
Shasha Xu \\ School of Electric and Information, Southwest Petroleum University, Chengdu, China \\ Email:xuss2016@163.com \\ Received 18 January 2016; accepted 21 February 2016; published 26 February 2016 \\ Copyright @ 2016 by authors and Scientific Research Publishing Inc. \\ This work is licensed under the Creative Commons Attribution International License (CC BY). \\ http://creativecommons.org/licenses/by/4.0/ \\ (c) (i) Open Access
}

\begin{abstract}
The development and continuous improvement of campus networks brings new changes to the campus and college life, more and more students are turning to micro-blog to express their views and opinions, and through the micro blogging to achieve fast and efficient sharing and exchange of information and resources. In the micro blog era, the power of micro blogging can not only impact college students, expand the breadth and depth of ideological and political education of college students, but also can enhance the ideological and political education of timeliness, interactive, fun, and thus enhance the effectiveness of the full and effective ideological and political education. In this paper we study the achievements and problems of both ideological and political analysis of the current situation of college students, and the effects of micro-blog on the ideological and political education, and actively explore the ideological and political education of college students in micro blogging era.
\end{abstract}

\section{Keywords}

Ideological and Political Education, Micro Blog, College Students, Southwest Petroleum University

\section{Introduction}

With the rapid development and popularization of computer networks and 3G communication technology, micro-Blog has become the new network communications tool and the rapidly rising one in today's society. The development and continuous improvement of campus networks brings new changes to the campus and college life, more and more students are turning to micro-blog to express their views and opinions, and through the mi- 
cro blogging to achieve fast and efficient sharing and exchange of information and resources. In this paper, through doing some research about the nature, we find the characteristics of micro blog communication and the ideological education of college students in the status and political education, and explore effective measures and reasonable method of ideological and political education of college students (Harvey, L. \& Green, D., 1993).

\section{The Current Ideological and Political Education Situation of the Student in Southwest Petroleum University}

\subsection{Achievements of Ideological and Political Education for College Students}

Southwest Petroleum University students are very valuable human resources and also the hope of the future of our nation. It is a must to strengthen and improve ideological and political education of them and improve their ideological and political quality, and train them into the qualified builders and socialist cause successors with Chinese characteristics is of profound strategic significance for the full implementation strategy of revitalizing the nation through science and education. It also has profound strategic significance to accelerate the grand goal of socialist modernization (Harvey, L. \& Knight, P. T., 1996). Over the years, our hospital administration in accordance with the requirements of the Party attaches great importance to ideological and political education of college students, earnestly implement the College strengthen ideological and political education of the relevant spirit. In Ideological and political education work, adhere to the student for this, wholeheartedly for the students to grow up to be useful service philosophy, and actively explore the inherent law of the ideological and political education, beneficial exploration in practice, try to embody the characteristics in the ideological and political education of college students, focused, pay attention to actual effect.

Cultivation of beauty comprehensive development socialist builder and successor, is the fundamental task of our higher education and Party building work. In the ideological and political education in institutions of higher learning, the growth of the student population is a positive, active, energetic, trustworthy and worthy group in our country. In the face of a major test of the moment, our outstanding young university students possess the quality concentrate more reflected. The reason is that the state, government, colleges and universities, in the education oriented, moral education for the first guiding principle, the system, the depth of the socialist core value system gradually formed the education to guide the healthy development of College Students, training a large number of talents for the construction of socialism with Chinese characteristics (Harvey, L. \& Williams, J., 2010). All in all, the new generation of receiving the ideological and political education as a reliable successor to the great cause of the Chinese characteristic society, it is positive, positive and dynamic posture for our country's modernization.

With government and enterprise and community joint effort, Insisting on scientific developing view as guidance, launched a series of new policies, new systems, new methods while promoting the rapid development of Ideological and political education of College Students, for college students' ideological and political education provides the essential guarantee.

\subsection{Problems of College Students' Thoughts Education}

Do a good job of ideological education of college students, but also to pay attention to changes in the situation at home and abroad (Hendry, G. D. \& Dean, S. J., 2002). Under the new situation, the complicated and changeable situation at home and abroad provides unprecedented opportunities for the ideological and political education of college students, and it is also a great challenge for the ideological and political education of college students. Only when we study the challenges of the ideological and political education of college students, can we do a good job in the ideological and political education of College students.

1) Globalization and the network makes college students have faith crisis.

With the further strengthen of the trend of economic globalization and the rapid development of modern information technology, the information spreading is becoming faster and faster, the coverage of spreading is more broad, these advanced technologies provide a rapid and convenient means for the positive contact and direct exchange of Western and Eastern cultures. Globalization is the first performance in the economic field, and penetrate into the social, ideological, cultural and other fields, changing the way of human production and life. In this form, all kinds of thoughts are interlaced with each other, the values of the west, ideology and way of life 
will have a great impact on college students. This diversified situation is likely to cause confusion and confusion in the mind, especially in certain western social thought, which seems to be progressive and scientific, in fact, denying the Marx doctrine. it has put forward higher requirements on the training quality of talents of colleges, Adhering to the correct faith has played an irreplaceable role in the ideological and political education for college students.

2) The lag of the content of ideological and political education

With unceasing development of economy, the rapid development of science and technology in our country and the market economy interest driven principle and the competition law under the new situation, the college students' ideological and political education content limitations, the science and technology related to the moral and ethical education and ideological and political education content lag, makes the ideological and political education lack of the sense of the times, cannot be deeply rooted in the hearts of the people, cannot solve practical problems for college students. Therefore, when all kinds of thinking and understanding problems of the long-term accumulation, cannot be properly resolved, these problems will be deeply rooted. At present, many moral problems related to science and technology have been exposed (Hutyra, M., 2005).

3) Environmental changes affect the formation of college students' correct views

The party and the government over the years to emphasize the coordinated development of material and spiritual civilization, but for a long time, the social economy, light the spirit of universal existence, on the construction of spiritual civilization is still insufficient attention, extent affected the optimization of the environment of the whole society. The negative factors, such as the style of the party, the public security and the cultural market, have a large number of negative factors, which have negative effects on the students. For example, some students lack of trust in the party and the government, to the policy of reform and opening-up lack of confidence; in some college students appear utilitarian, money oriented learning view and employment view; the lack of a correct value judgment, hedonism, egoism, money worship prevails.

For a long time, China's special attention to social and family ethics, society as a whole civilization of home environmental health, but social development bring positive influence to family environment, at the same time, but also bring great impact to some family environment. For example, some families are laid off and financial difficulties; some families become gambling sites; some parents are divorced and so on. These led to the family is not peace, the family is full of copper smell, indifference, violence, etc.. In addition, the only child of the times is coming, the parents unrealistic expectations, strict requirements makes the family is full of tension, the atmosphere of opposites. All these lead to family environment of Ideological and political education is difficult to play, which restricts the improvement of the efficiency of reflection and political education for College Students.

4) The mental health of college students is becoming more and more serious

Presently the psychological health of university students has become an increasingly conspicuous problem in moral education, which colleges and universities are confronted with and demands prompt solution. Confronted with manifold pressures and challenges from studying, life, and employment, university students are apt to be troubled by some psychological perplexities (Kim, J. W. \& Richarme, M., 2009). Talent quality naturally includes psychological quality, a college students have no good psychological quality, even if they have learned advanced knowledge, not qualified personnel, cannot afford the burden of future society. College students have many special problems, such as professional choice and learning adaptation, the ideal and the reality of conflict, interpersonal relationship, the contradictions in love and future work pressure problem. These problems have led to their psychological crisis or psychological barriers, and even physical and mental illness. Strengthen Students' mental health education, becoming a problem requiring urgent attention of all colleges and universities (Koilias, C., Kostoglou, V., Garmpis, A., \& Van der Heijden, B., 2011).

\section{Weibo Influence on Southwest Petroleum University Students' Ideological and Political Education}

With the development of Internet technology and the popularization of all kinds of terminal products, the Internet has become an important channel for people to obtain information, major web portals, search engines, social networking sites provide people with a wealth of timely information resources. Weibo with its vast amounts of content, quickly spread speed, how far the spread of the level, the spread of a wide range of communication effect become the important channel of information for college students. To publish and access to information is 
the core function of weibo, College students can use weibo in your spare time to achieve a larger range and a deeper sense of information exchange and sharing. In the era of weibo, users only need to log in weibo for message refreshes can understand the today's world. Unlike portals, search engines, as social networking microblogging in addition to providing general news, there is a large number of ordinary message, students can also use microblogging records has certain social awareness events around you, become the event producers and communicators. In addition, students used weibo when receiving information has a certain autonomy and selectivity. Can be based on their own interest in the subject of information on the issue of "concern”, "special attention”, can also refuse to receive information. All in all, microblog has become a key channel of the current college students, to share information, microblog also become the important collection and distribution center, the campus information college students focus on world events and social livelihood of the people, entertainment, leisure, etc have reflect on twitter.

Under the traditional teaching mode, the ideological and political education of college students is mainly based on the theory of concentration of time and place. This way of teaching lack of consciousness of service, interaction and democratic principles, often by educators to master the main power of discourse, of expression of the pedagogue lacks the corresponding rights and in a relatively passive receiving position, leading to quite a number of college students on the traditional ideological and political education, also greatly influence the education effect. Under this kind of background, weibo as a kind of new network applications bring new development opportunities for the development of college students' ideological and political education. On the microblogging platform, teachers and students have equal status and voice, the expression and participation of the two sides have been strengthened, it is conducive to promoting the exchange of views between teachers and students and emotional communication.

As a kind of based on attention mechanism to share brief even information broadcasting social networking platform, weibo with its brief content, broad scope, convenient transmission become favored by modern people's new information release platform. Traditional ideological and political education is mostly confined to specific space and practice, there are certain restrictions on information acquisition, sharing and dissemination. Weibo instant, stereo, multi-layer model cross space and time to a certain extent, and to enhance the ideological and political education information and coverage, the permeability of ideological and political education for college students provides a more convenient and effective information communication platform. Weibo rapid real-time remote communication can not only enhance college students' ideological and political education in the content and channel of timeliness, but also to broaden students’ horizons, enhance their social responsibility.

\section{Southwest Petroleum University Students' Ideological and Political Education in Micro Blog Era}

Micro blog, as a kind of new media with distinct characteristics of the times, has been widely used in college students, and its profound influence has changed the life and study of college students. For weibo's dual influence on college students' ideological and political education, colleges and educators should pay attention to information control work on one hand, as far as possible avoid weibo ideological bias, on the other hand, should also be fully aware of the microblogging positive significance for the work of ideological and political education, ideological and political guide college students to make use of its positive.

1) Have the courage to face challenges, create the ideological and political education of weibo communication platform. The traditional mode of Ideological and political education is difficult to keep up with the pace of the development of the times, but through the microblogging, education can not only grasp all kinds of information, can also understand the college students' ideological trend, thereby enhancing the effectiveness and pertinence of Ideological and political education. The traditional mode of Ideological and political education is difficult to keep up with the pace of the development of the times, but through the microblogging, education can not only grasp all kinds of information, can also understand the college students' ideological trend, thereby enhancing the effectiveness and pertinence of Ideological and political education. Therefore, the ideological and political education workers should actively study the new media, represented by the micro blog, to build a micro blog communication platform. Colleges and universities and the ideological and political education workers should take the initiative to open microblogging, pays attention to the student, and student establish benign interaction, select the most suitable persuasion and appeal of Ideological and political education information, and the use of microblogging concern, comment, forwarding, to communicate with students, immediate understanding of stu- 
dents' ideological changes, and to provide corresponding guidance and help.

2) The ideological and political educators should keep pace with The Times, weibo is used to establish harmonious and new relationship between teachers and students. The traditional ideological and political education is generally top-down, the educated in the education of the same time, the default of the education of the authority, therefore, the students have a sense of fear of teachers (Lee, J. W. \& Tai, S. W., 2008). The relationship between teachers and students is also more distant, students often do not dare to open their hearts to communicate with the teacher, which makes the ideological and political education effect is not good. But the heart of contemporary university students is keen to equal communication with teachers, and the emergence of weibo become relatively equal status to both sides, Students through weibo can communicate with the teacher and get to know each other, the close relationship between teachers and students. Therefore, educators should gradually adapt to this change, update ideas, set up in the weibo environment equal and harmonious relationship between teachers and students, so as to guide students to form correct value orientation, develop good moral character, made a very good ideological and political education.

3) Strengthen the network media quality education, guide students to the correct use of weibo. Network media literacy is that web users to use network information receiving and transmission in the network life should have the quality and accomplishment. In the face of the vast microblog information, college students' thought is not fully mature, it is easy to get lost, confused thinking. Therefore, it is necessary to strengthen the ideological and political education workers network media literacy education of college students, guide students to the correct use of weibo (Lagrosen, S., Seyyed-Hashemi, R., \& Leitner, M., 2004). Specific can be carried out from the following two aspects: First, the ideological and political education in Colleges and universities should strengthen the guidance on the life of College freshmen. After the University, a lot of college students addict to the Internet, cannot extricate themselves, abandoned their studies. Therefore, after the new students, the school should hold some lectures on the network, or invite some media professionals face-to-face communication with students, make students grasp some knowledge of the network media, so as to guide students in life after learning the advanced tool, make good use of network to serve their own success. Second college courses in the network media and combine with the ideological and political education. Network is widely and profoundly influence the formation, change and development of people's ideological and moral character. It has become the place of modern ideological and political education. Facing the challenge of weibo and the weak ability of the students' media literacy, ideological and political education workers should be teaching in cultivating college students manage the ability of the network information and the use of the network media's ability to obtain knowledge.

4) Establish a mechanism for the network combined with the reality of education. Education should strengthen the weibo education and reality of complementary advantages, promote the further strengthening of ideological and political education reality and fully implemented. Under the traditional mode of education, ideological and political education work in teaching and management has strong predictability, but also greatly limit by the time and space. And weibo broke through the limit of time and space, but because of the influence of the whole network environment it had certain unpredictability. Weibo as an instant communication tool can make the ideological and political educators understand college students' psychological state and the first opinion idea, and educators can communicate by talking face to face so as to obtain well education effect.

\section{Conclusion}

This paper can help other scholars to research the related situation of college students' ideological and political education in universities and provide some beneficial reference. In addition, this study aimed at college students' ideological problems which caused analysis and countermeasures to explore and build scientific and effective ideological and political work mode of college students, which has a positive reference value. In this paper, we do some research about the mode of ideological and political education of college students in the micro blog era, the effect of the corresponding quantitative and qualitative analysis, can provide some bases for other scholars to conduct related research. Secondly, from the aspect of practical significance, strengthening and improving the ideological and political education of college students can not only enhance the college students' comprehensive quality and culture quality, promote the inevitable demand of China's higher education reform and development, but also maintain the stability of college and society, which is a key to the building of a harmonious socialist society. 


\section{References}

Harvey, L., \& Green, D. (1993). Defining Quality. Assessment and Evaluation in Higher Education, 18, 9-34. http://dx.doi.org/10.1080/0260293930180102

Harvey, L., \& Knight, P. T. (1996). Transforming Higher Education. Buchingham: Society for Research into Higher Education, Open University Press.

Harvey, L., \& Williams, J. (2010). Fifteen Years of Quality in Higher Education. Quality in Higher Education, 16, 3-36. http://dx.doi.org/10.1080/13538321003679457

Hendry, G. D., \& Dean, S. J. (2002). Accountability, Evaluation of Teaching and Expertise in Higher Education. International Journal for Academic Development, 7, 75-82. http://dx.doi.org/10.1080/13601440210156493

Hutyra, M. (2005). Quality Management System as the Part of University Management. Paper Presented at Integrating for Excellence, Sheffield, 15-17 June 2005.

Kim, J. W., \& Richarme, M. (2009). Applying the Service-Profit Chain to Internet Service Businesses. Journal of Service Science and Management, 2, 96-106. http://dx.doi.org/10.4236/jssm.2009.22013

Koilias, C., Kostoglou, V., Garmpis, A., \& Van der Heijden, B. (2011). The Incorporation of Graduates from Higher Technological Education into the Labour Market. Journal of Service Science and Management, 4, 86-96. http://dx.doi.org/10.4236/jssm.2011.41012

Lagrosen, S., Seyyed-Hashemi, R., \& Leitner, M. (2004). Examination of the Dimensions of Quality in Higher Education. Quality Assurance in Education, 12, 61-69. http://dx.doi.org/10.1108/09684880410536431

Lee, J. W., \& Tai, S. W. (2008). Critical Factors Affecting Customer Satisfaction and Higher Education in Kazakhstan. International Journal of Management in Education, 2, 46-59. http://dx.doi.org/10.1504/ijmie.2008.016230 